Embodied Petroleum*

Las In-corporaciones del Petróleo

As corporações de petróleo 


\section{duskin drum**}

Founding professor of the School of Advanced Studies University of Tyumen.

Correo electrónico: d.drum@utmn.ru

Revista Corpo-grafías: Estudios críticos de y desde los cuerpos / Volumen 6 - Número 6 / Enero - diciembre de 2019 /

ISSN impreso 2390-0288, ISSN digital 2590-9398 / Bogotá, D.C., Colombia / 188-201.

Fecha de recepción: 24 de mayo de 2018

Fecha de aceptación: 28 de agosto de 2018

Doi: https://doi.org/10.14483/25909398.14240

Cómo citar este artículo: drum, d. (2019, enero-diciembre). Embodied Petroleum. Revista Corpo-grafías: Estudios críticos de y desde los cuerpos, 6(6), 188-201 / ISSN 2390-0288.

*Artículo de investigación: This essay describes how several performances presence petroleum embodiment through participant bodily activities superimposed with representations of human petroleum relations.

El presente ensayo describe la manera como varios actos performativos traen a la presencia las in-corporaciones del petróleo, a través de sendas prácticas participativas, las cuales se superponen a las representaciones usuales de las interacciones humanas con este material.

** duskin drum ${ }^{1}$ [sic] was made by and by the forest and the sea and the people and the petroleum; he is part of the making. duskin is an interdisciplinary scholar, artist, performer, and woodsman. He is a founding professor of the School of Advanced Studies of Tyumen University. In 2017, duskin completed a doctorate in Performance Studies with emphases in Native American Studies and Science and Technology Studies at University of California, Davis. In 2005, he earned a Bachelors of Arts studying interdisciplinary theatre and performance at Evergreen State College. For twenty years, duskin has been making art and performance in Asia, Europe and the Americas. At the School of Advanced Studies, his interdisciplinary research group, Material Relations, is devising a new theory of love for studying ecologically substantiating human-nonhuman relations including technological relations. His website can be found at http://undeveloping.info

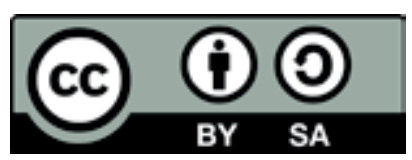

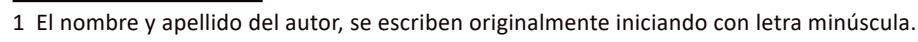




\section{Abstract}

This essay describes how several performances presence petroleum embodiment through participant bodily activities superimposed with representations of human petroleum relations. After introducing techniques for presencing petroleum, the essay focuses on one aspect of performer and participant reaction to petroleum presence. Audiences and performers alike resist becoming petroleum in these performances. They compulsively insist they are not only reducible to petroleum embodiments. The hyper-presencing of petroleum embodiment triggers a negative capacity of being not petroleum. These performative absences invite change. Possibly even demands change.

Keywords: petroleum; petro-cultures; environmental humanities, petroleum performance, indigenous jurisprudence; ecological performance; embodiment.

\section{Resumen}

El presente ensayo describe la manera como varios actos performativos traen a la presencia las in-corporaciones del petróleo, a través de sendas prácticas participativas, las cuales se superponen a las representaciones usuales de las interacciones humanas con este material. Luego de introducir diferentes técnicas para poder presenciar el ser del petróleo, el ensayo se enfoca en un aspecto en particular de la reacción del artista y del participante frente a la presencia del petróleo. En estos actos performativos, tanto los artistas como los participantes se resisten a devenir-petróleo. De manera insistente, ellos enfatizan que no pueden ser reducidos a las prácticas corporales ligadas a la infraestructura del petróleo. La 'hiper-presencia' de las incorporaciones del petróleo desencadena una capacidad negativa de ser 'no-petróleo'. Estas ausencias performativas invitan al cambio, y, posiblemente, hasta lo reclaman.

Palabras clave: petróleo; culturas del petróleo; humanidades ambientales; performance del petróleo; jurisprudencia indígena; performance ecológico; corporalización.

\section{Resumo}

O presente ensaio descreve a maneira pela qual vários atos performativos trazer corporações de petróleo para a presença, através de práticas participativas, que se sobrepõem às representações usuais das interações humanas com este material. Depois de introduzir diferentes técnicas para poder testemunhar o ser do petróleo, o ensaio enfoca um aspecto particular da reação do artista e do participante à presença do petróleo. Nesses atos performativos, tanto artistas como participantes resistem a devenir-petróleo. Insistentemente, eles enfatizam que não podem ser reduzidos a práticas corporais ligadas à infraestrutura de petróleo. A 'hiper-presença' das incorporações de petróleo provoca uma capacidade negativa de ser 'não petróleo'. Essas ausências performativas convidam à mudança e, possivelmente, até a exigem.

Palavras-chave: petróleo; culturas de petróleo; humanidades ambientais; performance de óleo; jurisprudência indígena; performance ecológico; corporalização. 
Into the absence. To say America is addicted to oil is insufficient. Water is a better comparison than opioids or cocaine. This essay introduces a small gathering of performances that presence petroleum embodiment. These performances presence petroleum embodiment by tracing petroleum causation and figuration in everyday life and fixing audience attention on these petroleum causes and figures. Each performance brings into embodied psychic attention essential existential collaborations with petroleum. This makes present or brings into active attention our somatic and spiritual connections with petroleum.

-I would not be without petroleum.

-This world, as I live it, as I know it, could be not be without petroleum.

-This space/time continuum I am experiencing is delivered and manifest through collaborations/complicity with petroleum. Strangely, even current and future atmospheres and oceans are modulated by our petroleum interactions. $^{2}$

This essay introduces performance techniques for presencing petroleum embodiments and environments of contemporary human bodies and habitations. For the purposes of this essay, to presence (Hunter, 2014, 2016) is to open audiences to participation with their own petroleum selves and habitats, and process of the performative acts/tools of study and description assembling manifestations of a body or an environment (Law, 2004). After introducing the performances, I focus on one aspect of participant reaction to petroleum presence. Audiences and performers alike resist becoming petroleum. They compulsively insist they are "not only" 3 reducible to petroleum embodiments and causes. The hyper-presencing of petroleum embodiment triggers a negative capacity of being not petroleum. Negative, because every positive manifestation of our bodies and selves are partially petroleum caused. Yet, the performances stimulate an opening to other imaginings. Imagine absent embodiments. As poet John Keats wrote "I mean Negative Capability, that is when man is capable of being in uncertainties, Mysteries, doubts, without any irritable reaching after fact \& reason" (1818). Though every reaching for fact returns to petroleum produced worlds, the performativity of the petroleum hyper-saturation stimulates opening to unperceived or occluded possible figurations (Haraway, 1990; Lykke, Markussen, \& Olesen, 2004; Strathern, 2004). In performance studies, Lynette Hunter uses the term "alongside" to describe the possible figurations made present by this kind of performative opening (Hunter, 1999; 2014, 68; 2016). The notion of human bodies and habitation, embodiment and 


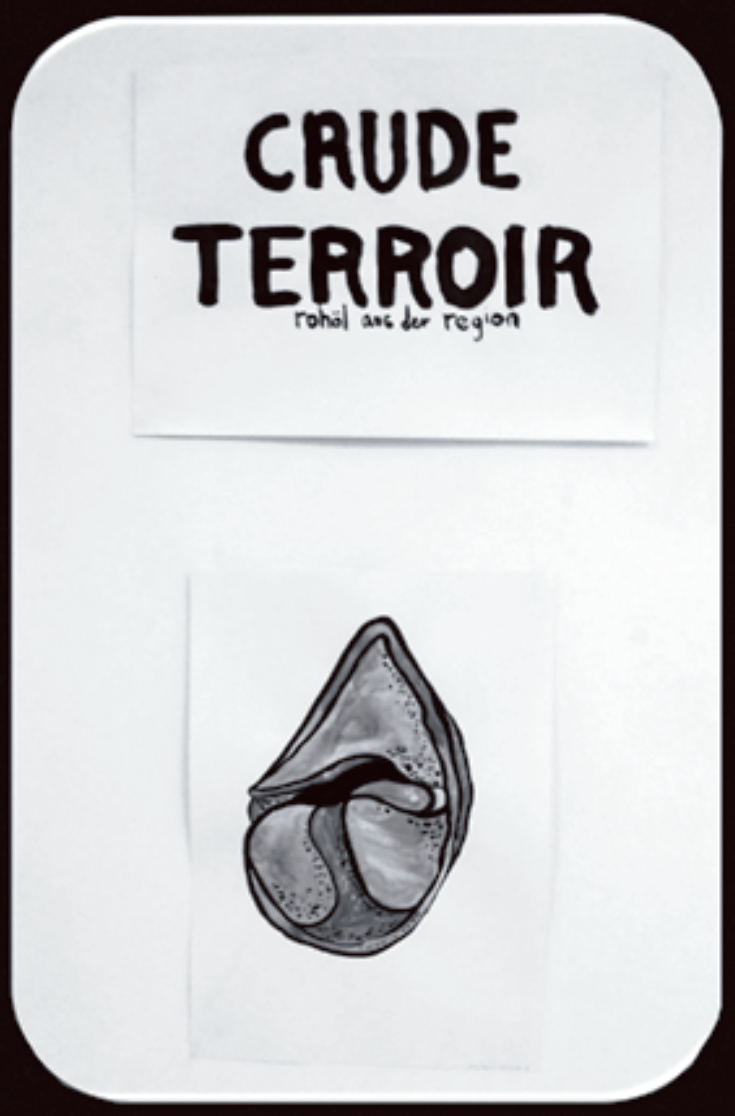

Figure 25. Crude Terroir. Photo: duskin drum. 2013 circumstance without petroleum is a performative absence. Imagine subtracting the petroleum causes that have fed, arranged, and located you and your circumstances. The body without petroleum is absent, even impossible, in the material causation of the bodies performing and participating in the performances. Yet, in my experience, performance participants continue to resist conceptually becoming petroleum. In part, they resist embodying the ethical burden of the effects of petroleum extraction, processing and combustion but they also open to alongside possibilities. The performative absence of petroleum free bodies invites change. Possibly even demand change.

I want to suggest some participation in public political performances against petroleum devices and infrastructures are stimulated in part by this performative absence of petroleum free humanity. As an example, in 2016-17 at Standing Rock Sioux lands in South Dakota, Native Americans, other Indigenous peoples, and their supporters attempted to bodily prevent the construction of a crude oil pipeline (NYC Stands with Standing Rock, 2016). At this and other anti-

petroleum direct action spectacles, petroleum embodiments (contemporary humans) are resisting petroleum. They assert and affirm, we are not only petroleum. In my experience and observations, the negative presence, the present absence of human living without petroleum is fertile ground for the rejuvenating injunctions of place-based law, indigenous jurisprudence. Indigenous jurisprudence is a way of naming traditional customs and jurisdictions kept fully contemporary by indigenous-led environmental justice struggles, especially those configured around homelands (Alfred \& Corntassel, 2005; Awiakta, 1993; Black, 2010; Borrows, 2002, 2005; Coulthard, 2010, 2014; LaDuke, 1999; Napoleon, 2007, 2013; Parisi \& Corntassel, 2007; L. Simpson, 2004). 


\section{The Petroleum Performances}

I offer a small collection of petroleum performances; performances about the performance of petroleum in contemporary human ecology. Every performance is participatory. Each is crafted to make it difficult for the participants to hold back and watch from the sidelines. Participation frames the performances and draws the audiences.

\section{We Are Petroleum ${ }^{4}$}

We are petroleum was devised to trigger for participants something like the experience of researching petroleum enactments and enchantments, while learning from indigenous devotion to their cultural and materially substantiating non-human relatives (drum, 2016; drum, 2017). I became emotionally and empirically overwhelmed by the fact of petroleum relations materially and energetically substantiating to nearly every aspect of contemporary human life. Concurrently, I became even more acutely aware of the tremendous ecological and cultural damages induced by petroleum mining, processing, and combustion. The performance participants are drawn into collectively reflecting about their petroleum material and cultural substantiation. They consider living and dying in a petroleum-enacted world through reading a Gwich' $n^{5}$ syntax of living and dying in a caribou enacted world. The performance centers on short emulations of snatches of Gwich'n diplomat Sarah James' congressional testimony and pamphlets and position papers prepared by the Gwich'n Steering Committee (Arctic Coastal Plain Leasing, 1995; Sarah James, 2000) Gwich'in Steering Committee, 2004, 2005). The emulations were generated by simply replacing "caribou" with "petroleum" and adjusting the details. The emulations enunciate an American ${ }^{6}$ petroleum cosmology by poaching the syntax of "we are caribou people." "We are petroleum people." The Americans do live in petroleum, travel by petroleum, dance petroleum dances and petroleum is their sacred way of life. Participants read the emulations aloud in small groups of three to eight people.

\footnotetext{
4 forestmongrel.undeveloping.info/?p=239

5 The Gwich'in are an indigenous people whose homelands are in northeastern Alaska and northwestern Canada. For decades, they have been preventing oil and gas development in the calving grounds of the Porcupine Caribou herd. The herd sustains them and their identity.

6 In the performance, "Americans" referred explicitly to people of the United States and Canada, but the revelations of the performance can easily apply, with slightly more violence, to Central and South America. Consider the fraught petroleum macro-politics of Venezuela, Brazil, Mexico, Ecuador, and Peru, and the micro-politics, like in North America, the petroleum delivers food, bodies, and supplies.
} 


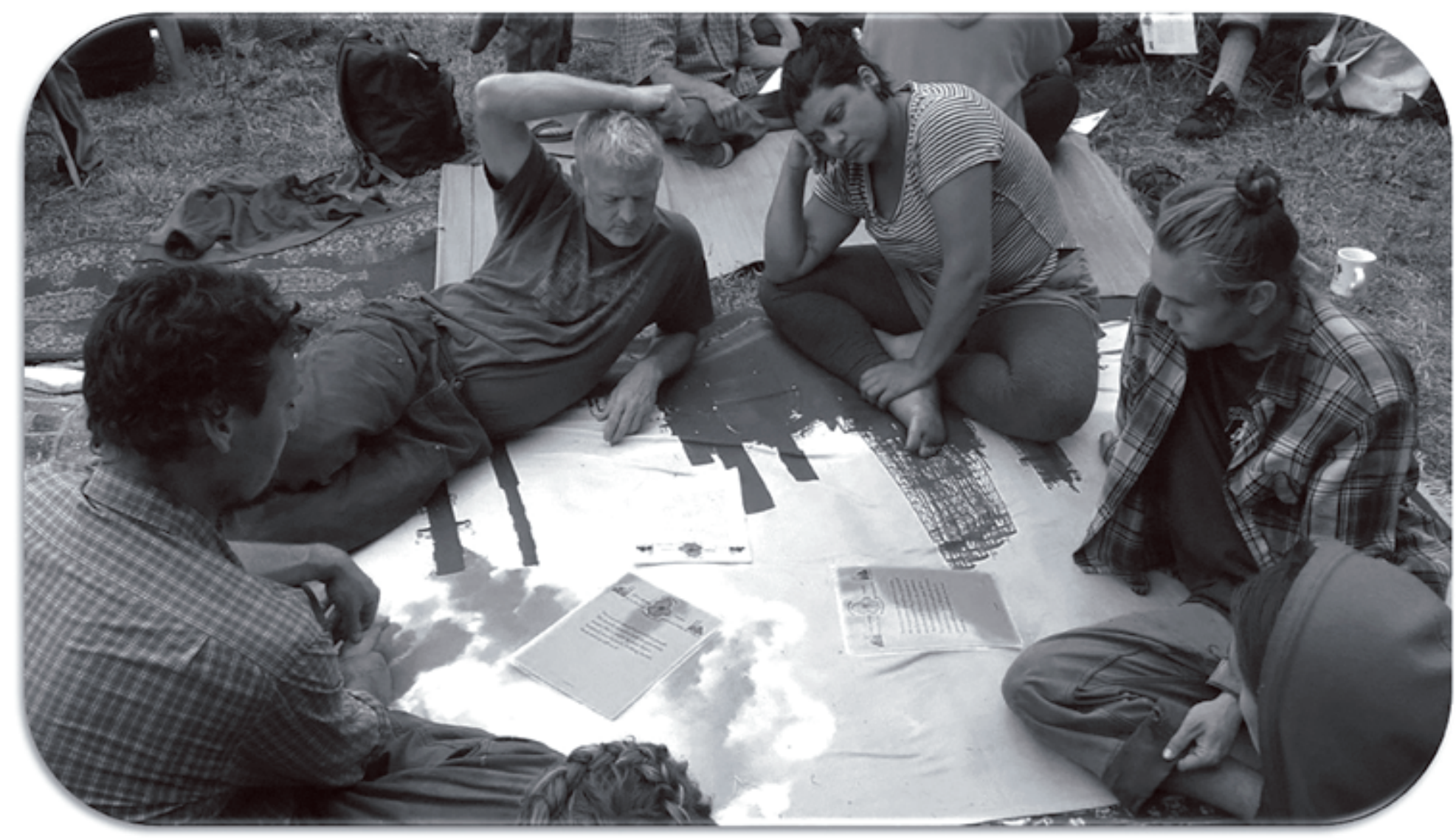

Figure 26. We are petroleum people performance documentation. Photo: duskin drum. 2017.

After twenty minutes they have read all the emulations several times and begin a discussion. Sometimes they lapse into a somber brooding silence. Then they discuss. Finally, in one big group, the original Gwich'in statements are read alternating with their respective petroleum emulations. After reading through once or twice, the group has a big discussion. This presencing of petroleum embodiment works through rhetoric of substitution and comparison of caribou sustenance for petroleum sustenance. It also performs a figurative translation that changes (expands) how participants conceptualize and articulate their existential connections to petroleum. 


\section{Market Fitness: Commodity Futures ${ }^{7}$}

Created by Christian Nagler and Azin Seraj, Market Fitness: Commodity Futures (2013) is an unnatural combination of an economics lecture and American aerobics class (Nagler, 2014a, 2014b). Nagler lectures and leads the audience in aerobics against the backdrop of Seraj's stunning footage of Nagler doing the aerobics in commodity landscapes; in a cow field, inside an oil refinery. "Fitness" is not just ironic, nor is it satire. It is experientially embodied, participatory, and pedagogical. Nearly an hour long, the workout exhausts most participants. The participants disparately burn calories in bodies already being ecologically and economically sustained by petroleum commodity chains. Popular imaginaries and subjectivities of health and physical image depend upon petroleum providing the conditions for sedentary laboring bodies seeking physical fitness through activity. Every participant in a performance of Market Fitness embodies contradictions of petroleum civilization. They are tangibly and visibly burning excess energy made possible by petroleum. Market Fitness presences petroleum capacitation of bodies with the speculative economic instruments of petroleum supplies. Personal fitness is part of the labor of economic speculation (Nagler, 2014). In some ways, each participant is a metonymic embodiment of financial workers.

The performance makes present petroleum embodiment by juxtaposing two registers of petroleum. First, the textual verbal description of petroleum trading superimposed with footage of a refinery. Second, the aerobics routine makes present the easy calories of petroleum food systems and bodies needing supplementary exercise just to be "fit."

\section{Peripatetic Presencing of Petroleum Landscapes and Spacetime}

I want to draw attention to two kinds of contemporary art practices and environmental justice education that presence petroleum. First are practices of tracing, visiting, and walking around petroleum installations. Second are practices of longer durational walking or even cycling the landscapes of petroleum.

Firstly, on tours, drifts and explorations of local petroleum infrastructures participants experience a performative double, their bodies themselves present in tracing the systems that support these bodies, and transport them into consumer "survival" enchantment. It is like walking in your own intestines. Especially when visiting oil fields, chemical plants or oil refineries the local horror of the leaky, messy, stinky, and massive installations amplifies the desire to disassociate from these organs of human survival. Concurrently, the placement, scale of production, and 
interconnectedness of the infrastructures reminds this is an essential performance in modern life (Bloom, 2015; drum, 2017; Huber, 2013; LeMenager, 2014; Misrach \& Orff, 2012). Participants experience an internal and often discussed estrangement between their cognitive understanding of the necessity of the infrastructure as we know it, and their bodily curiosity, discomfort, and revulsion in the presence of the stinking clouds of gas and suspicious sticky mud. The estrangement can be amplified further by talking with people who live in the mud and under the cloud. This is a well-established method of environmental justice also called "toxic tours" (Pezzullo, 2009). In artistic and creative social practices, these walks and tours are articulated as studying the landscapes and infrastructures producing our lives through troubling material and ethical entanglements with petroleum. In ethnographic fieldwork studying crude pipelines in Southern Illinois, I found pipeline workers have hyperaware sensibility of their essential connection to petroleum (drum, 2017). Their close work with the infrastructure made the normally invisible and ignored hyper-present. One informant even described this connection in terms of a gift from God and expressed a cosmological calling to burn it.

The second method of peripatetic presencing of petroleum embodiment is walking and cycling across the petroleum landscapes. Not hiking in the national park, but walking in landscapes, like the Midwest of the United States, configured and shaped by highways, roads, bridges and petroleum-powered monoculture agriculture. This is not the countryside, "this an industrial wasteland" (B. Drum, personal communication). This performative practice presences petroleum embodiment in landscape. The distance by foot is so far. Super highways become barriers and obstacles. The figurative power of petroleum-assisted travel becomes present, the petroleum infrastructure for petroleum travel. Slowing down and slipping temporarily out the timings and distances bodily understood in terms of cars, buses, and planes and trains, the body become disjointed from the everyday naturalized timings and spacing enacted through petroleum means. On one such walk, walkers, of the Compass collective on a continental drift through the Midwest Cultural Corridor came to characterize this landscape presence of petroleum as petroleum space/time continuum (Compass Group, 2014; Continental Drift et al., 2009; Groves, 2012).

\section{Outside the Work: Feasting on deep temporality of petroleum ${ }^{8}$}

Briefly, in yet another sensorial approach to presencing petroleum embodiment, artist Marina Zurkov designed, prepared and served a meal based on deep temporal creation of petroleum. Outside the Work: A Tasting of Hydrocarbons and Geological Time was an edible allegory presencing the consumption of deep temporality of

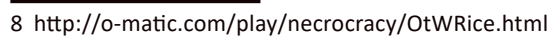


compressed biology becoming fossil fuels and shockingly rapid expansion of burning them (Zurkov, 2014). Just ate it all up in one night. Not even everyone got to eat. Did the servants get to try any? The allegory started with chlorophyll and algae, and ended with a dessert that required piercing geology-like crusts to drill for black liquid and suck it up. While, I have not the pleasure/horror of eating this feast, Zurkov's approach is another compelling method of presencing petroleum embodiment.

Present Absence: Embodiments without Petroleum

To all these performances, there is one participant response I want to put center stage. Audiences, participants, and performers, will agree, yes, I am petroleum embodied and/or petroleum performed. But - the performative - "but, but, but , but... I'm not just a petroleum embodiment.... I'm more than that" remains. Initially, some people resist the evidence of being causally created and capacitated by petroleum, but then it often sinks in, there is a period of self-reflection, maybe anguish, sometimes relief at recognizing openly they are embodiments of petroleum actions.

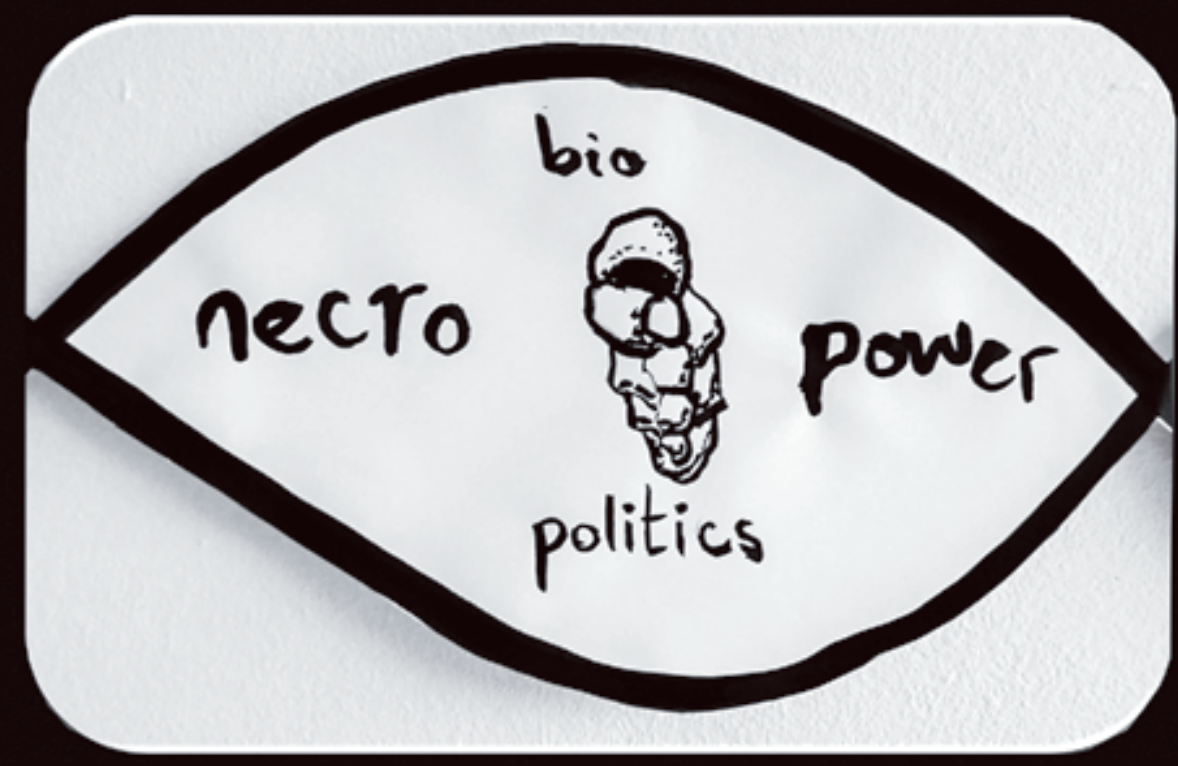

Figure 27. Exotica bonbons. Photo: duskin drum. 2013. 
Some perhaps sink into a petro-melancholia driven petroleum nihilism. But often, there is a further response to the petroleum presencing; I am more than petroleum. Yes, I am completely dependent and specifically placed herewith and in because of it/them. But there, I am more or could be different. While this might be a reassertion of denial, I want to suggest this is a kind negative presencing that invites possibilities for speculating and dreaming, maybe craving, life other than petroleum life. Without petroleum something else will happen. With less petroleum something else will happen. The hyper-presencing of petroleum embodiment triggers a negative capacity of imagining being not petroleum.

For me it has become as habitual seeking looping thoughts, what about walking, what about eating...? what about growing...? what about...? what about...? and each "what about" is and can be challenged, dissolved, by the petroleum that got it there, or is hidden in there. In Petro-subjectivity, Brett Bloom's extended textual contemplation of bicycles, often considered a solution, realizes bicycles are embodiments of petroleum actions (2015). But the petroleum explanation does not necessarily close down the negative capacity of the presencing of petroleum. Lately, Bloom's creative social work has turned to sensorial and ecological workshops for tuning to the world other than and after petroleum ${ }^{9}$. Of course, sadly, thankfully, we cannot get away from the atmosphere and oceans and their reactions to petroleum.

Getting into the negative presence of petroleum, or the imagined absence of petroleum opened me to other stories and other relations including more sensitivity and responsiveness to injunctions of indigenous jurisprudence and non-symbolic communications of places. Indigenous jurisprudence is placed-based legal structures and processes, partial restrictions on human actions locally and best practices for relations with place and the other relations that constitute place - good for place, good for people (Black, 2010; Borrows, 2002; Napoleon, 2007; L. Simpson, 2008). In North America, indigenous jurisprudence is sustained by and asserts jurisdiction through traditionalists, writers and artists, aspects of tribal governments, environmental justice groups and, of course, places themselves. The injunctions of these legal systems are not completely free of petroleum, but rather they have distinction and reference to living successfully in places without aid of petroleums. They echo with resonances of different temporalities, different spacetimings, different property regimes, and different measures of belonging (Deloria, 2012; Goeman, 2013; Manuel, 1974; Simpson, 2014; Vizenor, 2008).

9 https://www.breakdownbreakdown.net/ 


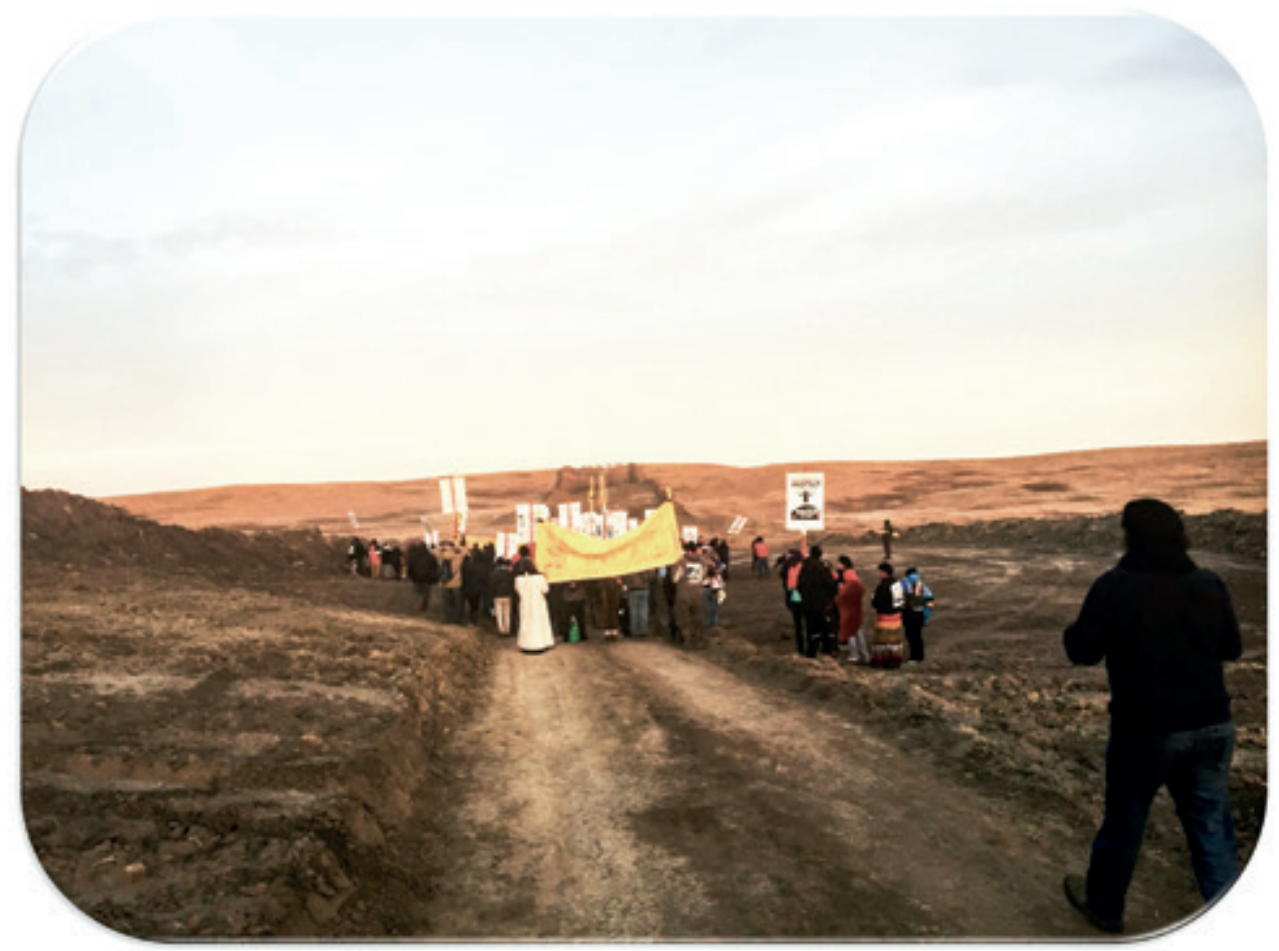

Figure 28. Water protectors. Photo: Bochay Drum. 2016.

In 2016-17 within Standing Rock Sioux territories, thousands of petroleum embodiments (human people) attempted to prevent another pipeline of petroleum capacitation. Following the injunction of youths and finding motivation in prophecy (indigenous jurisprudence), petroleum bodies fought against what is good for them, against their own petroleum embodiment. Their actions are a performative reach into an absence figured and made conscious by petroleum presencing. Their intense and fervent struggle was a manifestation of the power of a virtual nonpetroleum human alongside. The strong material struggle of negative capacitated embodiments speaks.

The small gathering of petroleum performances in this essay demonstrates techniques of paralleling representation (information about petroleum) with performance of participant bodies. Bodies and their imaginations are drawn into the rhetorical figure. Relatively simple juxtapositions and parallels activate performative wavering, or intertexual play (Hunter, 1999), between embodiment and representational knowledge. In We are Petroleum participants perform an embodied act of speaking aloud for the petroleum people and caribou people, acknowledging petroleum embodiment but troubled by knowledge of ways of life dying for petroleum. In Market Fitness participant petroleum bodies with excess energy are alongside a lecture on commodity trading in front of images of refineries. In the peripatetic performances participants move, bodies move, among the industrial bodies of petroleum infrastructures 
and landscapes. By tracing infrastructures, sites of production, and experiencing environmental injustices petroleum bodies are filled with doubts. But at the same time they feel their lack of autonomy from petroleum causes. Similarly, in Outside the Work: A Tasting of Hydrocarbons and Geological Time petroleum capacitated bodies fed on petroleum food systems eat an allegory of the creation of petroleum and its rapid exhaustion.

In these performances, presencing embodied and imagined contradictions and ambiguities of being petroleum and not being petroleum opens up performative possibilities, perhaps opening to spirits and recollections of nonpetroleum humanity. Become medium for them.

\section{References}

Acher, D. \& Brovkin, V. (2008). The Millennial Atmospheric Life Time of Anthropogenic CO2. Climate Change, 90, 283-297. DOI 10.1007/s10584-008-9413-1 Alfred, T., \& Corntassel, J. (2005). Being Indigenous: Resurgences against contemporary colonialism. Government and Opposition, 40(4), 597-614. Awiakta, M. (1993). Selu: Seeking the corn-mother's wisdom. Fulcrum Pub.

Black, C. F. (2010). The land is the source of the law: a dialogic encounter with indigenous jurisprudence (Taylor and Francis e-Library Kindle Edition). London [u.a.: Routledge].

Bloom, B. (2015). Petro-Subjectivity (1 edition). Half-Letter Press. Retrieved from: http://www.breakdownbreakdown.net/ Borrows, J. (2002). Recovering Canada: The resurgence of indigenous law. University of Toronto Press. Borrows, J. (2005). Indigenous legal traditions in Canada. Wash. UJL \& Pol'y, 19, 167.

Compass Group. (2014, November 9). Glossary | Compass [dedicated to the exploration, enlargement, critique and celebration of the Midwest Radical Cultural Corridor]. Retrieved November 9, 2014, from: http://midwestcompass.org/glossary/

Continental Drift, Compass, Bloom, B., Brown, N., Fortun, B., Lewison, S. ... Ross, S. (2009, March). Articulating the Region from Below: From Deep Within the Midwest Radical Culture Corridor. Presented at the The City from Below, Baltimore, MD. Retrieved from: http://anarchitektur.org/oa_camp/ files/10dfoa_03_BrettBloom.pdf

Coulthard, G. (2010). Place against Empire: Understanding Indigenous Anti-Colonialism. Affinities: A Journal of Radical Theory, Culture, and Action. Retrieved from: https://ojs.library.queensu.ca/index.php/affinities/article/view/6141

Coulthard, G. (2014). Red Skin, White Masks: Rejecting the Colonial Politics of Recognition. Minneapolis: Univ Of Minnesota Press.

de la Cadena, M. (2014). Runa: Human but not only. HAU: Journal of Ethnographic Theory. 4(2), 253-259.

de la Cadena, M. (2015). Earth beings: Ecologies of practice across Andean worlds. Duke University Press.

Deloria, V. (2012). The metaphysics of modern existence. Golden, Colo.: Fulcrum.

drum, duskin. (2016). we are petroleum. Participatory performance. Retrieved from: http://forestmongrel.undeveloping.info/?p=239

drum, duskin. (2017). Petroleum Performance. University of California, Davis: PQDT Open. Retrieved from: https://pqdtopen.proquest.com/ doc/1947710098.html?FMT=ABS

drum, D. (2017). Somos petróleo. Tabula Rasa. 26, 101-122.

Goeman, M. (2013). Mark my words: native women mapping our nations. Minneapolis: University of Minnesota Press.

Groves, J. (2012, September 17). Anthropocen(tr)ic Theory [Haus der Kulturen der Welt]. Retrieved October 27, 2014, Retrieved from: http://www. synapse.info/blog/guest-post-anthropocentric-theory-by-jason-groves/

Gwich'in Steering Committee. (2004). Protect the Sacred Place Where Life Begins. Gwich'in Steering Committee. Retrieved from: http://ourarcticrefuge. org/resources/ 
Gwich'in Steering Committee. (2005). A Moral Choice for the United States. Gwich'in Steering Committee. Retrieved from: http://ourarcticrefuge.org/wpcontent/uploads/2012/10/GSChumanrightsreport.pdf

Haraway, D. (1990). A manifesto for cyborgs: Science, technology, and socialist feminism in the 1980s. Feminism/Postmodernism. 190-233.

Huber, M. T. (2013). Lifeblood: oil, freedom, and the forces of capital. Minneapolis: Universit of Minnesota Press.

Hunter, L. (1999). Critiques of Knowing: Situated Textualities in Science, Computing and The Arts (1 edition). London ; New York: Routledge.

Hunter, L. (2014). Disunified Aesthetics: Situated Textuality, Performativity, Collaboration. McGill-Queen's University Press.

Hunter, L. (2016). Ethics, performativity and gender: porous and expansive concepts of selving in the performance work of Gretchen Jude and of Nicole Peisl. Palgrave Communications, 2, 16006. https://doi.org/10.1057/palcomms.2016.6

James, S. Arctic coastal plain leasing: on leasing of the 1002 area of the Arctic National Wildlife Refuge (ANWR) to the oil exploration and development industry. § Committee on Resources (1995). Washington, DC.: Washington : Retrieved from:

http://hdl.handle.net/2027/pst.000025002744

James, S. (2000, December). An interview with Sarah James regarding the Arctic Wildlife Refuge. Retrieved from: http://www.duncanentertainment.com/ james.php

Keats, J. (2018, August 2). Selections from Keats's Letters [text/html]. Retrieved August 3, 2018, from: https://www.poetryfoundation.org/articles/69384/ selections-from-keatss-letters

LaDuke, W. (1999). All our relations: native struggles for land and life. Cambridge, MA: South End Press.

Law, J. (2004). After method: mess in social science research. London ; New York: Routledge.

LeMenager, S. (2014). Living Oil: Petroleum Culture in the American Century (1 edition). New York, NY: Oxford University Press.

Lykke, N., Markussen, R., \& Olesen, F. (2004). Cyborgs, Coyotes and Dogs : A Kinship of Feminist Figurations; There Are Always More Things Going on Than You Thought! Methodologies as Thinking Technologies. An Interview with Donna Haraway, conducted in two parts. In The Haraway Reader. Routledge, 321-343. Retrieved from: http://urn.kb.se/resolve?urn=urn:nbn:se:liu:diva-23423

Manuel, G. (1974). The Fourth World: an Indian reality. New York: Free Press.

Misrach, R., \& Orff, K. (2012). Petrochemical America. Aperture Foundation.

Nagler, C. (2014a). Market Fitness Lecture 7: Commodities futures. Performance Research. 19(3), 176-178. https://doi.org/10.1080/13528165.2014.9351 84

Nagler, C. (2014b). What about "Market Fitness." Interviewed by duskin drum.

Nagler, C., \& Seraj, A. (2013). Market Fitness: Commodity Futures. Aerobic economics lecture presented at the Northern California Performance Platform, UC Davis.

Napoleon, V. (2007). Thinking About Indigenous Legal Orders. National Centre for First Nations Governance. Retrieved from: http://fngovernance.org/ ncfng_research/val_napoleon.pdf

Napoleon, V. (2013). Thinking About Indigenous Legal Orders. In R. Provost \& C. Sheppard, eds. Dialogues on Human Rights and Legal Pluralism. Springer Netherlands, 229-245. Retrieved from: http://link.springer.com/chapter/10.1007/978-94-007-4710-4_11

NYC Stands with Standing Rock. (2016, October 11). \#StandingRockSyllabus. Retrieved August 3, 2018. Retrieved from:

https://nycstandswithstandingrock.wordpress.com/standingrocksyllabus/

Parisi, L., \& Corntassel, J. (2007). In pursuit of self-determination: Indigenous women's challenges to traditional diplomatic spaces. Canadian Foreign Policy Journal. 13(3), 81-98. https://doi.org/10.1080/11926422.2007.9673444

Pezzullo, P. (2009). Toxic Tourism: Rhetorics of Pollution, Travel, and Environmental Justice (1 edition). University Alabama Press.

Simpson, A. (2014). Mohawk Interruptus. Duke University Press.

Simpson, L. (2004). Anticolonial Strategies for the Recovery and Maintenance of Indigenous Knowledge. The American Indian Quarterly. 28(3), 373-384.

https://doi.org/10.1353/aiq.2004.0107

Simpson, L. (2008). Looking after Gdoo-naaganinaa: Precolonial Nishnaabeg Diplomatic and Treaty Relationships. Wicazo Sa Review. 23(2), 29-42. https:// doi.org/10.1353/wic.0.0001

Strathern, M. (2004). Partial connections. Walnut Creek, CA: AltaMira Press.

Vizenor, G. R. ed. (2008). Survivance: narratives of Native presence. Lincoln: University of Nebraska Press.

Zurkov, M. (2014, March). Outside the Work: A Tasting of Hydrocarbons and Geological Time. Tasting/Participatory performance for 50 guests, Rice University. Retrieved from: http://o-matic.com/play/necrocracy/OtWRice.html 